Fery Abdul Choliq, Mintarto Martosudiro, Istiqomah \& Muhammad Fanhash Nijami, 2020.

Isolasi Dan Uji Kemampuan Bakteriofag Sebagai Agens Pengendali Penyakit Layu Bakteri

(Ralstonia solanacearum) Pada Tanaman Tomat. Journal Viabel Pertanian. (2020), 14(1)8-20

\title{
ISOLASI DAN UJI KEMAMPUAN BAKTERIOFAG SEBAGAI AGENS PENGENDALI PENYAKIT LAYU BAKTERI (Ralstonia solanacearum) PADA TANAMAN TOMAT
}

\author{
${ }^{1)}$ Fery Abdul Choliq, ${ }^{2)}$ Mintarto Martosudiro, ${ }^{3)}$ Istiqomah, ${ }^{4}$ Muhammad Fanhash Nijami \\ ${ }^{1,2)}$ Fakultas Pertanian Universitas Brawijaya, Jalan Veteran, Malang, Jawa Timur \\ ${ }^{3)}$ Fakultas Pertanian Universitas Islam Darul 'Ulum Lamongan, Jalan Airlangga \\ ${ }^{4)}$ Sukodadi, Lamongan, Jawa Timur \\ Email : ${ }^{1)}$ feryac@ub.ac.id, ${ }^{3)}$ istiqomah.faqih@gmail.com
}

\begin{abstract}
Tomato is the top priority in the development of horticultural crops. The obstacle which mostly encountered is Ralstonia solanacearum pathogen attack. Bacteriophage can cause bacterial lysis after they they develop themselves inside the bacteria. The specific of the bacteriophage can provide result quickly, accurately, and efficiently so that it can be used as an alternative to control bacterial wilt disease $R$. solanacearum environmentally friendly. This study aims to find out the effectiveness of bacteriophage to control the bacterial wilt disease $R$. solanacearum. The testing method are plaque assay, bacteriophage infections test in various dilutions, bacteriophage infection test in a liquid medium, and transmission electron microscopy test. In the greenhouse scale testing using a Completely Randomized Design (CRD) with 6 treatments and 4 replications. Quantitative data were analyzed using analysis of variance 5\% error level and followed by least significant different test level of $5 \%$. The results showed that bacteriophages can infect $R$. solanacearum. Bacteriophage can infect bacteria $R$. solanacearum indicated by the appearance of plaques in NA media, the declining value of absorbance spectophotometer, and can lyse bacterial cells from dilutions 10-1 to 10-9. The morphology of bacteriophages that infect $R$. solanacearum have hexagonal head structure and it have which is with a size of $200 \mathrm{~nm}$. In the greenhouse scale showed that the symptoms of $R$. solanacearum appear at 29 days after inoculation. Application of bacteriophages can control $R$. solanacearum with lower percentage than the control treatment.
\end{abstract}

Keyword : Bacteriophage, Ralstonia solanacearum, tomato

\section{PENDAHULUAN}

Tanaman tomat (Lycopersicum esculentum) adalah termasuk sayuran yang banyak dibudidayakan dan sebagai salah satu sayuran yang memiliki prioritas utama dalam pengembangan hortikultura (Biratu et al., 2013). Tahun 2018, terdapat lima komoditas sayuran semusim dengan produksi terbesar secara berurutan adalah bawang merah, kubis, cabai rawit, kentang, dan cabai besar (BPS, 2018). Tomat tidak termasuk dalam 5 komoditas sayuran semusim dengan produksi terbesar, hal ini dikarenakan adanya kendala dalam budidaya tomat. Salah satu penyebab menurunnya produksi tomat adalah penyakit layu bakteri Ralstonia solanacearum (sebelumnya bernama Pseudomonas solanacearum) yang dapat merusak budidaya tomat di daerah tropis dan subtropis di seluruh dunia (Saleim et al., 2014). Kehilangan hasil produksi tomat mencapai 75-100\% bila ditanam pada lahan yang terinfeksi bakteri tersebut (Dahal et al., 2009). Oleh karena itu, bakteri $R$. solanacearum ditempatkan pada posisi kelima paling berbahaya di dunia (Elphinstone, 2005). 
Fery Abdul Choliq, Mintarto Martosudiro, Istiqomah \& Muhammad Fanhash Nijami, 2020.

Isolasi Dan Uji Kemampuan Bakteriofag Sebagai Agens Pengendali Penyakit Layu Bakteri (Ralstonia solanacearum) Pada Tanaman Tomat. Journal Viabel Pertanian. (2020), 14(1)8-20

$R$. solanaceaum adalah termasuk jenis bakteri gram negatif. Bakteri ini termasuk patogen tular tanah dan air dari famili Ralstoniaceae. Bakteri $R$. solanacearum memiliki kisaran inang yang luas dengan lebih dari 200 spesies dari 53 famili yang berbeda (Kawasaki et al., 2007). R. solanacearum menginfeksi melalui perakaran tanaman tomat yang terluka atau melalui lubang alami pada akar. Bakteri kemudian mulai berkembang biak di dalam jaringan tanaman sehingga menganggu transport air dan garam mineral karena tersumbat oleh jutaan bakteri (Yamada et al., 2007). Tanaman yang terinfeksi bakteri $R$. solanaceareum mengalami klorosis, kerdil, layu, dan biasanya mati dengan cepat (Meng, 2013) oleh karena itu penyakit ini disebut penyakit layu bakteri.

Pengendalian penyakit $R$. solanacearum kebanyakan mengandalkan bakterisida. Penggunaan pestisida berupa bahan kimia antibakteri diketahui dapat menyebabkan gangguan pada kesehatan manusia dan lingkungan karena meninggalkan residu kimia yang mencemari kondisi sekitar pertanian dan lingkungan hidup. Alternatif pengendalian untuk mengendalikan penyakit layu bakteri adalah dengan pengendalian hayati menggunakan mikroba. Penggunaan pengendalian penyakit dengan cara pemanfaatan agensia hayati mempunyai kelebihan diantaranya dapat mengurangi pencemaran lingkungan dari bahan kimia (pestisida), bersifat lebih efisien, berkelanjutan, tidak merusak keragaman hayati, dan sesuai dengan cara pengendalian lainnya (Setiati et al., 2016). Salah satu mikroba yang dapat mengendalikan penyakit layu bakteri adalah bakteriofag (Addy et al., 2012).

Bakteriofag merupakan virus yang menginfeksi bakteri dan mampu membunuh sel bakteri secara langsung (Buana dan Wardani, 2014). Bakteriofag terdiri dari molekul asam nukleat yang dikelilingi oleh mantel protein yang disebut kapsid (Jofre et al., 2014). Bakteriofag hidup dan berkembang biak di dalam organisme seluler dibandingkan virus lainnya yang berkembang biak di dalam tubuh organisme lain yang multiseluler (Clokie et al., 2011).

Bakteriofag virulen (bakteriofag yang eksklusif menyebabkan lisis) memiliki kemampuan dalam menyerang bakteri dan tidak mempunyai pengaruh terhadap jenis sel lain (Snyder dan Champness, 2003). Sifat spesifik dari bakteriofag dapat memberikan hasil yang yang akurat, cepat, efesien, dan murah, (Susianto et al., 2014). Hal tersebut dibuktikan, bahwa bakteriofag yang menginfeksi bakteri $R$. solanacearum tidak dapat menginfeksi bakteri Xantomonas campestris (Addy et al., 2012). Sehingga bakteriofag dapat dimanfaatkan sebagai agens pengendali hayati dan deteksi pada spesies dan strain bakteri (Hagens dan Loesner, 2007).

Penelitian tentang bakteriofag merupakan penelitian yang masih terbatas di Indonesia, sehingga penelitian tentang potensi bakteriofag virulen sebagai agens biokontrol mengendalikan penyakit layu bakteri $R$. solanacearum pada tanaman tomat perlu dikaji. Penelitian ini diharapkan dapat memberi informasi dasar dalam upaya pengendalian penyakit layu bakteri $R$. solanacearum dengan memanfaatkan mikroorganisme bakteriofag yang ramah lingkungan.

\section{METODE PENELITIAN}

Penelitian dilaksanakan di Laboratorium Bakteriologi dan Rumah Kaca Jurusan Hama dan Penyakit Tumbuhan, Fakultas Pertanian, Universitas Brawijaya mulai bulan Januari sampai dengan Juli 2019. Sedangkan untuk identifikasi morfologi bakteriofag menggunakan Mikrosksop Transmisi Elektron di Departemen Kimia, Fakultas Matematika dan Ilmu Pengetahuan Alam, Universitas Gadjah Mada. Penelitian ini dilakukan 2 tahap yaitu pengujian tingkat laboratorium (invivo) dan pengujian tingkat rumah kaca (invitro). 


\section{Isolasi bakteriofag}

Sumber bakteriofag diperoleh dari sampel tanah pada perakaran tanaman tomat yang endemik penyakit layu bakteri $R$. solanacearum. Sampel tanah diambil secara acak di 3 titik pada satu diagonal tepat di daerah perakaran (rhizosfer) tanaman tomat. Sampel tanah tersebut kemudian dijadikan satu (dikompositkan).

Sebanyak $50 \mathrm{~g}$ tanah digojlok (shaker) selama 4 hari pada media YPG yang sudah diberi kultur bakteri $R$. solanacearum berumur 24 jam. Sampel tanah yang sudah digojlok kemudian diambil suspensinya dimasukkan pada tabung eppendorf. Kemudian dilakukan sentrifugasi dengan kecepatan $10.000 \mathrm{rpm}$ selama 15 menit hingga pelet dan supernatan terpisah. Supernatan yang terbentuk, diambil dan disaring menggunakan membran berpori (milipore) ke dalam tabung eppendorf baru. Sebanyak $100 \mu$ l supernatan yang diduga mengandung bakteriofag dan $50 \mu \mathrm{l}$ suspensi bakteri $R$. solanacearum (OD $10^{8}$ $\mathrm{CFU} / \mathrm{ml}$ ) ditambahkan ke media Natrium Agar (NA) yang sudah disiapkan, campuran tersebut kemudian diratakan dengan metode sebar (spread plate) dan dinkubasi selama 24 jam pada suhu ruang.

\section{Purifikasi dan perbanyakan bakteriofag}

Purifikasi bakteriofag merupakan kegiatan yang dilakukan untuk memperbanyak stok bakteriofag murni yang akan digunakan untuk pengujian-pengujian selanjutnya. Purifikasi bakteriofag bertujuan untuk mendapatkan lisat murni bakteriofag yang ditandai dengan munculnya koloni yang memiliki morfologi dan ukuran plak yang sama (Nindita dan Wardani, 2013).

Perbanyakan bakteriofag dilakukan dengan cara mengambil koloni plak tunggal yang tampak di permukaan media NA. Plak tersebut kemudian dicongkel dengan menggunakan jarum ose sebanyak 1-2 plong lalu dimasukkan ke dalam tabung Erlenmeyer yang berisi media fage cair sebanyak $50 \mathrm{ml}$. Plak yang sudah diambil kemudian ditumbuk sampai halus dan ditambahkan suspensi bakteri $R$. solanacearum (OD $10^{8} \mathrm{CFU} / \mathrm{ml}$ ) sebanyak $100 \mu \mathrm{l}$. Suspensi yang sudah dibuat kemudian digojlok sampai homogen selama $1 \times 24$ jam. Suspensi yang sudah homogen kemudian disimpan pada suhu $16^{\circ} \mathrm{C}$.

\section{Uji plak (Plaque assay)}

Pengujian plak (Plaque assay) dilakukan dengan menggunakan metode tetes (spot test) yang bertujuan untuk mengetahui keberadaan dari bakteriofag yang ditandai adanya kenampakan batas cincin lisis infeksi bakteriofag dan mendapatkan koloni murni bakteriofag yang diperoleh dari strain bakteri $R$. solanacearum. Kultur bakteri $R$. solanacearum (OD $10^{8} \mathrm{CFU} / \mathrm{ml}$ ) diambil sebanyak $50 \mu \mathrm{l}$ diratakan di permukaan media NA dan TTC dengan menggunakan triangle glass sampai kering. Lisat bakteriofag diteteskan di permukaan media NA dan TZC sebanyak $2 \mu$ l dengan menggunakan mikropipet dan diinkubasi selama $24-48$ jam pada suhu $28^{\circ} \mathrm{C}$ (Susianto et al., 2014). 


\section{Uji kemampuan bakteriofag menginfeksi bakteri $R$. solanacearum secara in vitro pada berbagai tingkat pengenceran}

Stok lisat bakteriofag disiapkan untuk dilakukan perhitungan konsentrasi total bakteriofag dari lisat bakteriofag tersebut. Perhitungan konsentrasi bakteriofag dilakukan pada pengenceran $10^{-1}$ sampai $10^{-15}$ dengan mengambil lisat bakteriofag yang sudah murni sebanyak $100 \mu$ l. Perhitungan konsentrasi bakteriofag menggunakann prinsip yang sama dengan perhitungan konsentrasi bakteri yakni dengan Standart Plate Count (SPC). Pada bakteriofag yang dihitung yakni terbentuknya plak (plaque) dengan satuan PFU/mL (Plaque Forming Unit/ml) yang didapatkan dengan menggunakan metode spread plate dan diinkubasi selama 1x24 jam (Nindita dan Wardani, 2013).

Uji aktifitas penghambatan bakteriofag terhadap bakteri $R$. solanacearum pada media cair secara in vitro

Uji aktifitas penghambatan ini dilakukan untuk mengetahui efektifitas bakteriofag dalam menghambat pertumbuhan bakteri patogen. Uji ini dilakukan dengan menggunakan 2 perlakuan yang terdiri dari perlakuan kontrol dengan bakteri patogen (tanpa penambahan phage lysate) dan perlakuan kedua yakni bakteri patogen dengan penambahan phage lysate. Pada perlakuan pertama, kultur bakteri $R$. solanacearum dimasukkan ke dalam media NB sebanyak $100 \mu$ l yang berumur $18-24$ jam $\left(1 \times 10^{5}\right.$ $\mathrm{CFU} / \mathrm{ml}$ ). Perlakuan kedua yakni kultur bakteri $R$. solanacearum berumur 18-24 jam $\left(1 \times 10^{5} \mathrm{CFU} / \mathrm{ml}\right)$ dimasukkan ke media NB dengan perbandingan $100 \mu \mathrm{l}$ bakteri patogen dan ditambahkan phage lysate sebanyak $100 \mu$ l. Pengamatan uji penghambatan ini dilakukan dengan mengukur nilai optical density (OD) pada spektofotometer dengan panjang gelombang $600 \mathrm{~nm}$ setiap 6 jam (Bicalho et al., 2009).

\section{Karakterisasi bakteriofag dengan Mikroskop Transmisi Elektron (Transmission} electron microscopy)

Phage lysate dengan konsentrasi $10^{8} \mathrm{PFU} / \mathrm{ml}$ sebelumnya disaring dengan menggunakan membran berpori $0,22 \mu \mathrm{m}$ dan dimurnikan dengan disentrifugasi selama 60 menit dengan kecepatan $25.000 \mathrm{rpm}$. Kemudian diberi 0,1 ammonium asetat. Setetes lisat fag murni diendapkan pada grid tembaga yang berlapis karbon kemudian diwarnai dengan Pholy thongstid acid dan diperiksa pada mikroskop elektron transmisi dengan kekuatan $60 \mathrm{Kv}$. Hasil tangkapan gambar kemudian diukur bedasarkan ukuran kaki dan kepala (Manjunath et al., 2013).

\section{Uji aplikasi bakteriofag pada tanaman tomat secara in vivo (skala rumah kaca)}

Pengujian ini bertujuan untuk mengetahui efektifitas bakteriofag yang diaplikasikan pada tanaman tomat dalam menghambat serangan penyakit layu bakteri $R$. solanacearum pada tanaman tomat. Pada pengujian ini menggunakan rancangan acak lengkap (RAL) yang terdiri dari 6 perlakuan dan 4 kali ulangan (Tabel 1). 
Fery Abdul Choliq, Mintarto Martosudiro, Istiqomah \& Muhammad Fanhash Nijami, 2020.

Isolasi Dan Uji Kemampuan Bakteriofag Sebagai Agens Pengendali Penyakit Layu Bakteri (Ralstonia solanacearum) Pada Tanaman Tomat. Journal Viabel Pertanian. (2020), 14(1)8-20

Tabel 1. Perlakuan yang digunakan untuk aplikasi di rumah kaca.

\begin{tabular}{ll}
\hline No & \multicolumn{1}{c}{ Perlakuan } \\
\hline 1 & Bakterisida (Bahan aktif Streptomisin sulfat $20 \%$ ) + R. solanacearum (kontrol \\
& positif) \\
2 & Aquades $+10 \mathrm{ml}$ suspensi $R$. solanacearum (kontrol negatif) \\
3 & Bakteriofag pengenceran $10^{-4} \mathrm{PFU} / \mathrm{ml}+R$. solanacearum \\
4 & Bakteriofag pengenceran $10^{-5} \mathrm{PFU} / \mathrm{ml}+R$. Solanacearum \\
\hline 5 & Bakteriofag pengenceran $10^{-6} \mathrm{PFU} / \mathrm{ml}+R$. Solanacearum \\
\hline 6 & Bakteriofag pengenceran $10^{-7} \mathrm{PFU} / \mathrm{ml}+R$. Solanacearum \\
\hline
\end{tabular}

Media tanam yang digunakan terdiri dari tanah dan kompos dengan perbandingan 1:1 yang disterilisasikan dengan menggunakan formalin $4 \%$ selama 2 minggu. Bahan tanam yang digunakan yakni benih tanaman tomat varietas permata. Bakteri $R$. solanacearum yang sudah ditumbukan, dipanen dan dihomogenkan dengan aquades steril dengan kerapatan $10^{8} \mathrm{CFU} / \mathrm{ml}$. Sebelum melakukan inokulasi, perakaran tanaman tomat dilukai dengan cara memotong beberapa bagian bulu akar. Inokulasi bakteri $R$. solanacearum dilakuakan dengan cara menuangkan suspensi sebanyak $10 \mathrm{ml}$ di atas permukaan tanah.

Aplikasi bakteriofag dilakukan dengan cara membiakkan bakteriofag pada media NB yang sudah berisi kultur bakteri $R$. solanacearum selama 18 jam. Bakteriofag dan bakteri $R$. solanacearum kemudian dibiakkan kembali selama 48 jam. Setelah itu, suspense disentrifuge dengan kecepatan $10.000 \mathrm{rpm}$ selama 15 menit sehingga mendapatkan supernatant. Supernatan yang didapatkan kemudian diencerkan dengan berbagai tingkat pengenceran dan akan digunakan untuk percobaan skala rumah kaca. Aplikasi bakteriofag dengan berbagai pengenceran sebanyak $10 \mathrm{ml}$ diaplikasikan dengan cara dituangkan ke permukaan tanah setelah inokulasi bakteri $R$. solanacearum yang telah diinkubasi selama $1 \times 24$ jam (Zhang et al., 2014). Variable pengamatan pengujian rumah kaca yaitu masa inkubasi penyakit layu bakteri, kejadian penyakit.

\section{ANALISIS DATA}

Data yang diperoleh pada penelitian ini dianalisis menggunakan analysis of variance (ANOVA) taraf kesalahan 5\%. Apabila hasilnya berbeda nyata pada taraf kesalahan 5\%, maka analisis data dilanjutkan dengan menggunakan uji Beda Nyata Terkecil (BNT) taraf kesalahan 5\%.

\section{HASIL DAN PEMBAHASAN}

\section{Hasil isolasi dan purifikasi bakteriofag}

Hasil isolasi bakteriofag diinokulasikan pada koloni bakteri $R$. solanacearum adalah terbentuk plak-plak pada media NA dalam cawan Petri. Secara makroskopis, setelah masa inkubasi selama 1x24 jam terbentuknya plak-plak tersebut diduga karena lisisnya sel-sel bakteri $R$. solanacearum yang terinfeksi oleh bakteriofag. Plak-plak yang terbentuk sangat banyak dengan jumlah lebih dari 250 plak dalam satu cawan Petri. Berdasarkan hasil penelitian Murugaiyan (2010), Hasil isolasi bakteriofag dari sampel tanah perakaran tanaman tomat, cabai dan tembakau yang endemik $R$. solanacearum di Korea memiliki jumlah plak yang sedikit yakni lebih dari 100 plak. 
Fery Abdul Choliq, Mintarto Martosudiro, Istiqomah \& Muhammad Fanhash Nijami, 2020.

Isolasi Dan Uji Kemampuan Bakteriofag Sebagai Agens Pengendali Penyakit Layu Bakteri

(Ralstonia solanacearum) Pada Tanaman Tomat. Journal Viabel Pertanian. (2020), 14(1)8-20

\section{Hasil uji plak (Plaque assay)}

Pada pengamatan secara makroskopis tampak plak yang muncul dengan ditandai adanya zona lisis yang bening pada permukaan media NA yang sudah dilapisi bakteri $R$. solanacearum. Sedangkan pada pengamatan secara mikroskopis, terlihat kenampakan batas dari lisisinya sel bakteri (lysis ring) oleh bakteriofag yang terlihat sangat jelas (Gambar 1).

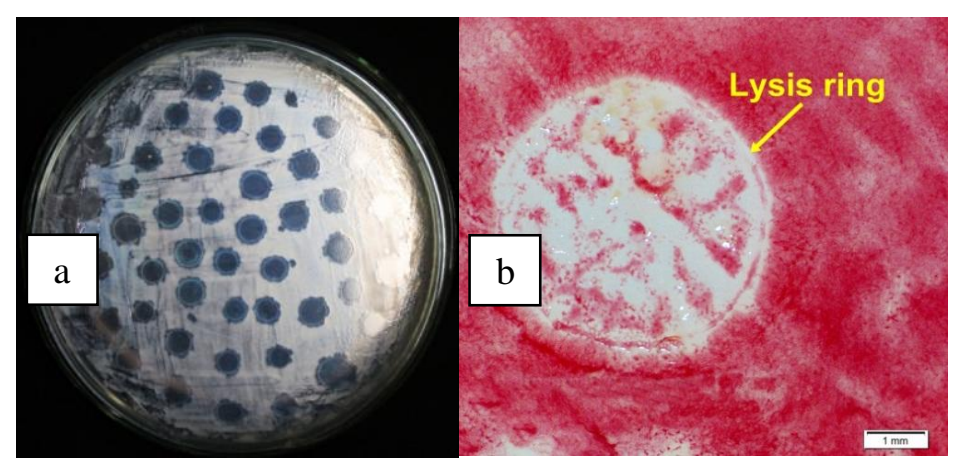

Gambar 1. (a) Kenampakan plak yang diperoleh dari hasil purifikasi dengan menggunakan metode spot test. (b) Kenampakan lisis sel tunggal infeksi bakteriofag pada media selektif TTZ

Berdasarkan hasil penelitian Liana et al., (2016) menyebutkan bahwa pada hasil uji plak terdapat zona lisis (lysis ring) yang transparan pada permukaan media tripton agar yang dilapisi bakteri E. coli akibat infeksi bakteriofag T4 (Gambar 14). Yamada et al., (2007) menyebutkan bahwa isolate bakteriofag dengan kode RSA 1, RSB1 dan campuran dari keduanya dapat menyebabkan lisis pada permukaan bakteri $R$. solanacearum selama 2-3 jam.

Hasil uji kemampuan bakteriofag menginfeksi bakteri $R$. solanacearum secara in vitro dengan berbagai tingkat pengenceran

Pengujian infeksi bakteriofag menunjukkan adanya korelasi antara jumlah bakteriofag (berbagai tingkat pengenceran) dengan jumlah plak yang terbentuk. Semakin tinggi konsentrasi lisat bakteriofag yang ditambahkan, maka jumlah plak yang muncul juga banyak.

Hasil pengamatan secara makroskopis menunjukkan bahwa pada perlakuan kontrol dengan menggunakan aquades tidak tampak adanya plak yang muncul, berbeda pada pengenceran bakteriofag $10^{-1}$ hingga $10^{-4}$ menghasilkan jumlah plak yang tidak dapat dihitung karena jumlah plak lebih dari 250 plak dalam satu cawan Petri. Sedangkan pengenceran lisat bakteriofag $10^{-5}$ hingga $10^{-9}$ plak yang terbentuk dapat dihitung. Jumlah plak yang muncul sesuai dengan menurunnya konsentrasi lisat bakteriofag yang ditambahkan. Pada pengenceran terakhir $10^{-10}$, sudah tidak ditemukan aktifitas litik bakteriofag yang ditandai dengan tidak terbentuknya plak (Tabel 2). 
Fery Abdul Choliq, Mintarto Martosudiro, Istiqomah \& Muhammad Fanhash Nijami, 2020.

Isolasi Dan Uji Kemampuan Bakteriofag Sebagai Agens Pengendali Penyakit Layu Bakteri (Ralstonia solanacearum) Pada Tanaman Tomat. Journal Viabel Pertanian. (2020), 14(1)8-20

Tabel 2. Kemampuan bakteriofag dalam menginfeksi bakteri $R$. solanacearum setelah dilakukan seri pengenceran

\begin{tabular}{rccc}
\hline No & Perlakuan pengenceran & $\begin{array}{c}\text { Jumlah plak yang muncul } \\
\text { tiap cawan Petri }\end{array}$ & Plak yang terbentuk \\
\hline 1 & Akuades (kontrol) & 0 & Negatif (Tidak lisis) \\
2 & $10^{-1}$ & TBUD & Positif (Lisis) \\
3 & $10^{-2}$ & TBUD & Positif (Lisis) \\
4 & $10^{-3}$ & TBUD & Positif (Lisis) \\
5 & $10^{-4}$ & TBUD & Positif (Lisis) \\
6 & $10^{-5}$ & 215 & Positif (Lisis) \\
7 & $10^{-6}$ & 207 & Positif (Lisis) \\
8 & $10^{-7}$ & 107 & Positif (Lisis) \\
9 & $10^{-8}$ & 53 & Positif (Lisis) \\
10 & $10^{-9}$ & 9 & Positif (Lisis) \\
11 & $10^{-10}$ & 0 & Negatif (Tidak lisis) \\
\hline
\end{tabular}

Keterangan: TBUD: Terlalu banyak untuk dihitung ( $<250$ plak dalam satu cawan Petri)

Bakteriofag dapat menginfeksi sel bakteri $R$. solanacearum pada pengenceran $10^{-1}-$ $10^{-9}$. Setelah dilakukan pengenceran hingga $10 \mathrm{x}$, jumlah polulasi bakteriofag yang terkandung di dalam suspensi juga berbeda. Hal ini menunjukkan bahwa semakin tinggi tingkat pengenceran yang dilakukan, maka semakin rendah konsentrasi dari bakteriofag yang terkandung di dalam suspensi. Berbeda dengan hasil penelitian Taj et al., (2014) yang menunjukkan bahwa bakteriofag melakukan aktivitas litik pada $10^{-1}$ hingga $10^{-7}$. Sedangkan pada pengenceran $10^{-8}$ hingga $10^{-10}$, bakteriofag tidak menunjukkan aktivitas lisis.

Hasil uji aktifitas penghambatan bakteriofag terhadap bakteri $R$. solanacearum pada media cair secara in vitro $\left(\mathrm{OD}_{600}\right)$

Pelisisian bakteriofag terhadap bakteri $R$. solanacearum dapat diindikasikan dengan melihat nilai Optical Density (OD) spektofotometer pada panjang gelombang 600 $\mathrm{nm}$. Hasil dari pengamatan yang dilakukan setiap 6 jam menunjukkan bahwa pada perlakuan A (kontrol) yaitu tanpa penambahan phage lysate terlihat pertumbuhan sel bakteri $R$. solanacearum. Berdasarkan grafik terlihat peningkatan pertumbuhan bakteri $R$. solanacearum pada pengamatan 6 jam dan 12 jam yang ditandai dengan meningkatnya nilai OD (Gambar 2).

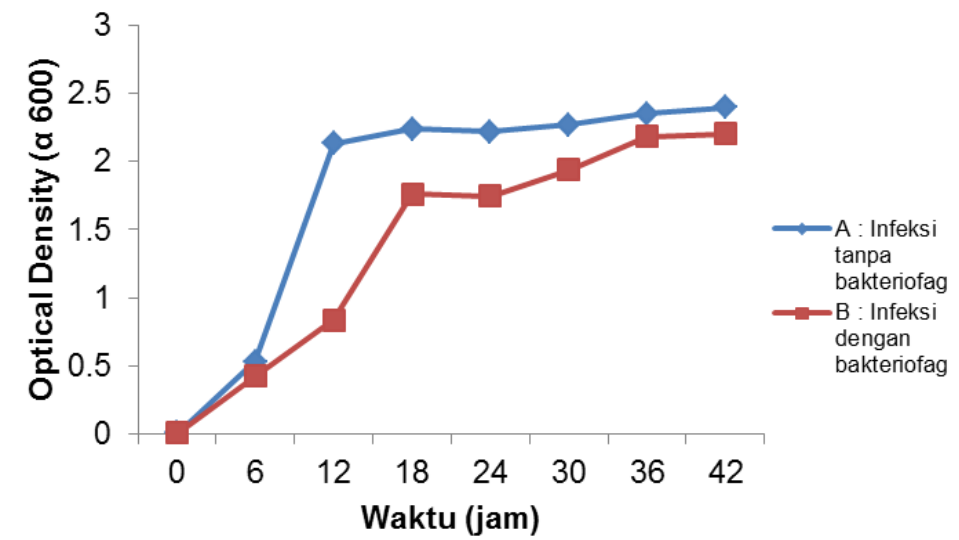

Gambar 2. Spektrum penghambatan bakteriofag terhadap bakteri $R$. solanacearum 
Fery Abdul Choliq, Mintarto Martosudiro, Istiqomah \& Muhammad Fanhash Nijami, 2020

Isolasi Dan Uji Kemampuan Bakteriofag Sebagai Agens Pengendali Penyakit Layu Bakteri (Ralstonia solanacearum) Pada Tanaman Tomat. Journal Viabel Pertanian. (2020), 14(1)8-20

Hasil yang didapatkan pada perlakuan B (dengan penambahan phage lysate) terlihat adanya penghambatan pertumbuhan bakteri $R$. solanacearum yang dilakukan oleh bakteriofag karena lisisnya sel-sel bakteri $R$. solanacearum. Nilai absorbansi yang lebih rendah ini diduga karena terjadinya proses pelisisan bakteri $R$. solanacearum oleh bakteriofag yang ditambahkan dalam media tumbuh. Menurut hasil penelitian Resita et al., (2013), menjelaskan bahwa bakteriofag dapat menekan pertumbuhan bakteri Pseudomonas syringae pada rasio terbaik dengan kemampuan infeksi MOI 10. MOI atau Multiplicity of Infection merupakan rasio atau perbandingan antara partikel bakteriofag dengan bakteri inangnya dalam satu suspensi larutan.

\section{Karakterisasi morfologi bakteriofag dan bakteri $R$. solanacearum yang terinfeksi dengan Mikroskop Transmisi Elektron (Transmission electron microscopy)}

Berdasarkan pengujian sampel bakteriofag yang sudah dilakukan dengan menggunakan Mikroskop Transmisi Elektron (Transmission electron microscopy), maka didapatkan hasil sampel bakteriofag yang menginfeksi bakteri $R$. solanacearum memiliki morfologi bagian kepala yang diduga memiliki struktur heksagonal dan mempunyai ekor dengan ukuran $200 \mathrm{~nm}$ (Gambar 3). Menurut hasil penelitian Frampton et al., (2014) menjelaskan bahwa 24 bakteriofag yang menginfeksi $P$. syringae pv. Actinidiae memiliki struktur kepala heksagonal dan keseluruhan termasuk ke dalam famili Myoviridae. Kawa (2014) mengatakan bahwa bakteriofag dari family Myoviridae mempunyai ekor yang panjang.

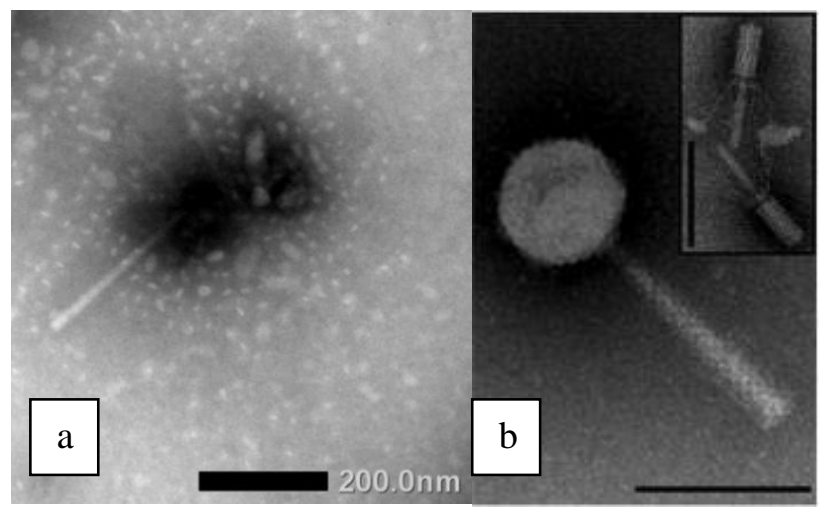

Gambar 3. Kenampakan morfologi bakteriofag. (a) yang menginfeksi bakteri $R$. solanacearum dengan menggunakan TEM, (b) morfologi bakteriofag Psa393 yang menginfeksi bakteri $P$. Syringae Pv. Actinidiae dengan menggunakan TEM (Frampton et al., 2014) 
Fery Abdul Choliq, Mintarto Martosudiro, Istiqomah \& Muhammad Fanhash Nijami, 2020.

Isolasi Dan Uji Kemampuan Bakteriofag Sebagai Agens Pengendali Penyakit Layu Bakteri (Ralstonia solanacearum) Pada Tanaman Tomat. Journal Viabel Pertanian. (2020), 14(1)8-20

Siklus litik bakteriofag yang menginfeksi bakteri $R$. solanacearum menyebabkan struktur lapisan dinding sel mengalami lisis (Gambar 4). Hal ini disebabkan oleh dinding sel bakteri $R$. solanacearum yang termasuk dalam bakteri gram negatif yang memiliki lapisan peptidoglikan yang tipis. Sehingga akan memudahkan bakteriofag dalam menginfeksi pada lapisan permukaan dinding sel bakteri. Morfologi dari bakteri $R$. solanacearum berbentuk basil dan memiliki struktur yang tidak memiliki flagel dengan lapisan dinding sel yang terlihat lisis.
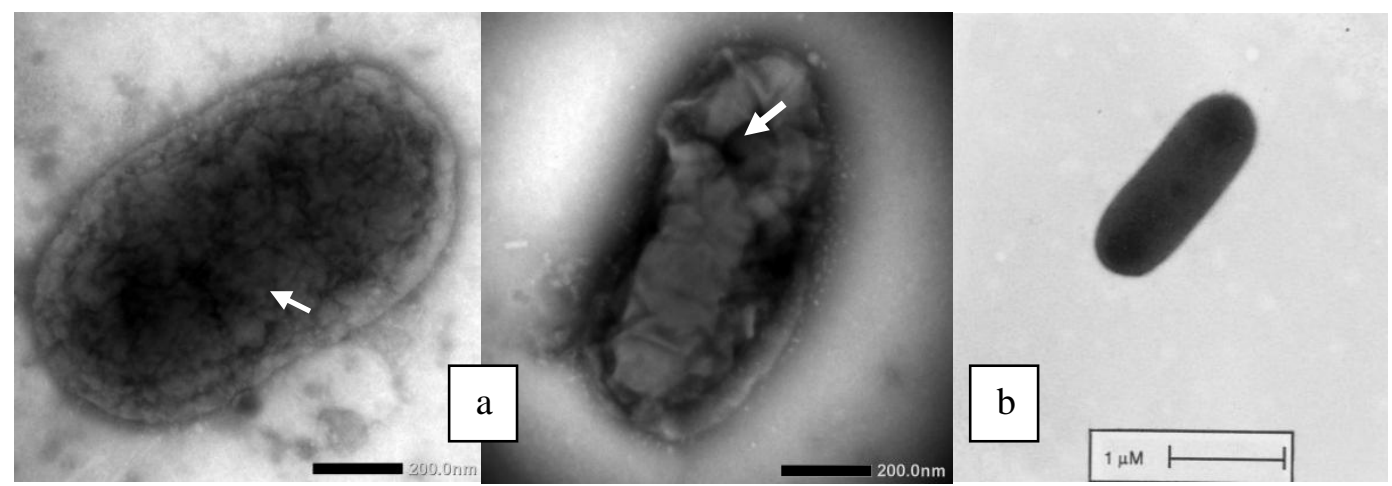

Gambar 4. Kenampakan Morfologi; a. Sel Bakteri R. solanacearum yang lisis (anak panah) dengan Manggunakan TEM, b. Morfologi Sel Bakteri $R$. solanacearum dengan Menggunakan TEM Strain K701 (Flic) (Kersten et al., 2001).

Hal ini didukung pada penelitian Kersten et al., (2001) yang menyatakan bahwa bakteri $R$. solanacearum K701 dan K724 hasil identifikasi dengan mikroskop transmisi elektron memiliki struktur tidak memiliki flagel dan berbentuk basil.

\section{Hasil pengujian di rumah kaca}

Berdasarkan hasil pengamatan yang sudah dilakukan menunjukkan bahwa gejala penyakit layu bakteri pada tanaman tomat sebagian besar muncul pada 29 hari setelah inokulasi. Gejala awal yang mulai muncul dan terlihat pada tanaman yaitu pada perlakuan P2 (kontrol negatif) dan P4 yakni beberapa daun mulai layu dan sedikit berwarna kuning. Berdasarkan hasil penelitian Maharina, (2014) menyatakan bahwa gejala penyakit layu bakteri $R$. solanacearum mulai muncul setelah 28 hsi. Gejala awal berupa daun mulai layu dan kekuningan hingga seluruh daun mengering. Hasil penelitian Istiqomah dan Kusumawati (2018) menunjukkan bahwa daun muda mengalami layu permanen selanjutnya layu juga terjadi pada bagian daun yang lain. Hal ini juga didukung oleh penelitian Kim et al., (2016) bahwa gejala penyakit layu bakteri muncul pada 14 hari setelah inokulasi dengan kerapatan bakteri $10^{8} \mathrm{CFU} / \mathrm{ml}$. 
Fery Abdul Choliq, Mintarto Martosudiro, Istiqomah \& Muhammad Fanhash Nijami, 2020.

Isolasi Dan Uji Kemampuan Bakteriofag Sebagai Agens Pengendali Penyakit Layu Bakteri (Ralstonia solanacearum) Pada Tanaman Tomat. Journal Viabel Pertanian. (2020), 14(1)8-20

Tabel 3. Rerata persentase (\%) kejadian penyakit layu bakteri ( $R$. solanacearum)

\begin{tabular}{|c|c|c|c|c|c|}
\hline \multirow[t]{2}{*}{ Perlakuan } & \multicolumn{5}{|c|}{$\begin{array}{l}\text { Rerata kejadian penyakit layu bakteri }(R \text {. solanacearum }) \\
\text { pada berbagai umur pengamatan }\end{array}$} \\
\hline & $1 \mathrm{MSI}$ & 2 MSI & 3 MSI & 4 MSI & $5 \mathrm{MSI}$ \\
\hline $\begin{array}{l}\text { Bakterisida (Streptomicin sulfat } \\
20 \%)+R s \text { (kontrol positif) }\end{array}$ & $7,50^{\mathrm{a}}$ & $12,50^{\mathrm{ab}}$ & $12,50^{\mathrm{ab}}$ & $15,00^{\mathrm{a}}$ & $17,50^{\mathrm{a}}$ \\
\hline Aquades $+R s$ (kontrol negatif) & $27,50^{\mathrm{b}}$ & $27,50^{\mathrm{b}}$ & $35,00^{\mathrm{b}}$ & $40,00^{\mathrm{b}}$ & $45,00^{\mathrm{b}}$ \\
\hline Bakteriofag $\left.10^{-4}+\mathrm{Rs}\right)$ & $2,50^{\mathrm{a}}$ & $5,00^{\mathrm{a}}$ & $7,50^{\mathrm{a}}$ & $12,50^{\mathrm{a}}$ & $17,50^{\mathrm{a}}$ \\
\hline Bakteriofag $\left.10^{-5}+\mathrm{Rs}\right)$ & $2,50^{\mathrm{a}}$ & $5,00^{\mathrm{a}}$ & $12,50^{\mathrm{ab}}$ & $22,50^{\mathrm{a}}$ & $25,00^{\mathrm{a}}$ \\
\hline Bakteriofag $\left.10^{-6}+\mathrm{Rs}\right)$ & $2,50^{\mathrm{a}}$ & $5,00^{\mathrm{a}}$ & $12,50^{\mathrm{ab}}$ & $17,50^{\mathrm{a}}$ & $20,00^{\mathrm{a}}$ \\
\hline Bakteriofag $\left.10^{-7}+\mathrm{Rs}\right)$ & $10,00^{\mathrm{ab}}$ & $15,00^{\mathrm{ab}}$ & $22,50^{\mathrm{b}}$ & $25,00^{\mathrm{ab}}$ & $25,00^{\mathrm{a}}$ \\
\hline
\end{tabular}

Keterangan : Data ditransformasikan ke Arc Sin $\sqrt{\mathrm{x}}+0.5$ untuk keperluan analisis ststistik dan dilanjutkan dengan uji beda nyata terkecil (BNT) pada taraf kesalahan 5\%. Angka yang diikuti oleh huruf yang sama pada kolom yang sama tidak berbeda nyata pada taraf kesalahan $0,05 \%$.

Berdasarkan hasil anailis ragam untuk kejadian penyakit layu bakteri menunjukkan bahwa pemberian bakteriofag memberikan pengaruh yang nyata dalam menekan penyakit layu bakteri $R$. solanacearum pada setiap umur tanaman. Kemudian setelah dianalisis dengan menggunakan uji lanjut bahwa pada perlakuan kontrol negatif yang memiliki persentase kejadian penyakit paling tinggi dan meningkat pada setiap waktu pengamatan (Tabel 3). Pada pengamatan terakhir, persentase kejadian penyakit layu bakteri pada perlakuan kontrol negative sebesar $45,00 \%$. Hal ini berbeda dengan perlakuan dengan pemberian bakteriofag yang dapat menekan insiden penyakit layu bakteri pada semua tingkat pengenceran.

Pada perlakuan kontrol negatif (tanpa pemberian agens hayati) menunjukkan kejadian penyakit layu bakteri semakin meningkat dari pengamatan 1 MSI - 5 MSI. Sedangkan pada perlakuan pemberian bakteriofag dan bakterisida memiliki rata-rata kejadian penyakit yang rendah dan relative konstan. Hal tersebut mengindikasikan bahwa aplikasi bakteriofag pada tanaman tomat efektif menekan pertumbuhan bakteri patogen $R$. solanacearum.

Berdasarkan hasil penelitian Yamada (2012), mengungkapkan bahwa keberhasilan dari bakteriofag sebagai agens biokontrol dipengaruhi oleh beberpa faktor yakni terdapat populasi pathogen yang menjadi target, menjaga stabilitas partikel bakteriofag dalam ekosistem, aplikasi bakteriofag dilakukan pada selama siklus tumbuh tanaman dan mengetahui kisaran inang dari bakteriofag dan memahami secara rinci tentang sifat dan karakter dari bakteriofag dan bakteri inang.

Lingkungan pada rumah kaca pada saat aplikasi bakteriofag memiliki suhu 25$30^{\circ} \mathrm{C}$ yang memungkinkan bakteriofag mampu beradaptasi dan melakukan aktifitasnya dalam menginfeksi bakteri $R$. solanacearum. Bakteriofag efektif dalam menghambat kejadian penyakit layu bakteri $R$. solanacearum dipengaruhi oleh beberapa faktor, yakni suhu, lingkungan, dan bakteri inang. Untuk kelangsungan hidup bakteriofag dipengaruhi oleh kondisi lingkungan, seperti $\mathrm{pH}$, suhu, intensitas cahaya, hujan dan radiasi (Irriate et al., 2007).

\section{KESIMPULAN}

Bakteriofag berpotensi sebagai agens hayati dalam mengendalikan penyakit layu bakteri $R$. solanacearum. Secara in vitro, bakteriofag yang sudah diisolasi memiliki sifat yang virulen yang ditunjukkan dengan adanya zona lisis pada permukaan media NA yang dilapisi bakteri $R$. solanacearum. Secara in vivo (uji virulensi), insiden penyakit layu 
Fery Abdul Choliq, Mintarto Martosudiro, Istiqomah \& Muhammad Fanhash Nijami, 2020.

Isolasi Dan Uji Kemampuan Bakteriofag Sebagai Agens Pengendali Penyakit Layu Bakteri (Ralstonia solanacearum) Pada Tanaman Tomat. Journal Viabel Pertanian. (2020), 14(1)8-20

bakteri dapat dikendalikan dengan pemberian bakteriofag. Sehingga memiliki persentase nilai kejadian penyakit yang rendah jika dibandingkan dengan perlakuan kontrol.

\section{DAFTAR PUSTAKA}

Addy HS, A. Askora, T. Kawasaki, M. Fujie, dan T. Yamada. 2012. Utilization of filamentous phage RSM3 to control bacterial wilt caused by Ralstonia solanacearum . Plant disease 96(8): 1204-1209.

Bicalho RC, T. Santos, R. Gilbert, LS. Caixeta, LM. Taixeira, Bicalho, dan Machado. 2009. Susceptibility of Escherichia coli Isolated from uteri of postpartum dairy cows to antibiotic and environmental Bacteriophages. Part I: Isolation and lytic activity estimation of bacteriophages. J. Dairy Science. 93: 93104.

Biratu KS, T. Selvaraj, T. Hunduma. 2013. In vitro Evaluation of Actinobacteria against Tomato Bacterial Wilt (Ralstonia solanacearum EF Smith) in West Showa, Ethiopia. J. Plant Pathol Microb. 4 (1).

BPS, 2018. Statistik Tanaman Sayuran dan Buah-buahan Semusim Indonesia 2018. https://www.bps.go.id/publication/2019/10/07/9c5dede09c805bc38302ea1c/statis tik-tanaman-sayuran-dan-buah---buahan-semusim-indonesia-2018.html. (Diakses 29 Maret 2020).

Buana EOGHN dan K. Wardani. 2014. Isolasi Bakteriofag Litik Sebagai Agen Biosanitasi Pada Proses Pelisisan Bakteri Pembentuk Biofilm. J. Pangan dan Agroindustri. Ind 2 (2): 36-42.

Clokie MRJ, AD. Millard, AV. Letarov, dan S. Heaphy. 2011. Phages in Nature. J. Bacteriofag 1 (1): 31-45.

Dahal D, D. Heintz, AV. Dorsselaer, HP. Braun, dan K. Wydra. 2009. Pathogenesis and stress related, as well as metabolic proteins are regulated in tomato stems infected with Ralstonia solanacearum. J. Plant Physiology and Biochemistry 47: 838-846.

Elphinstone JG. 2005. The Current Bacterial Wilt Situation: a global view. APS, Press, St. Paul, Minnesota, USA, pp. 9e28.

Frampton RA, C Taylor, AVH. Moreno, SB. Visnovsky, NK. Petty, AR. Pitman, PC. Fineran. 2014. Identification of Bacteriophages for Biocontrol of the Kiwifruit Canker Phytopathogen Pseudomonas syringae pv. Actinidiae. J. Applied and Environmental Microbiology 80(7).

Hagens S dan MJ. Loesner, 2007. Application of Bacteriophage for detection and control of foodborne pathogens. J. Application microbiology 76(3): 513-519.

Iriarte FB, B. Balogh, M. Momol, Smith, M. Wilson dan J. Jones. 2007. Factor Affecting Survival of Bacteriophage on Tomato Leaf Surface. J. Applied and environmental microbiology. 76(6): 1704-1711.

Istiqomah, I., Kusumawati, D.E., 2018. Pemanfaatan Bacillus subtilis dan Pseudomonas fluorescens dalam pengendalian hayati Ralstonia solanacearum penyebab penyakit layu bakteri pada tomat. J. Agro 5, 1-12.

Kawa D, T. Olszak, K. Danis, M. Skrobek, HW. Ackermann. 2014. A giant Pseudomonas phage from Poland. J. Virologi 159:567-572. 
Kawasaki T, H. Satsuma, M. Fujie, S. Usami, dan T. Yamada. 2007. Monitoring of Phytopathogenic Ralstonia solanacearum Cells Using Green Fluorescent ProteinExpressing Plasmid Derived from Bacteriophage $\varphi$ RSS1. J. Bioscience and bioengineering. 104(6): 451-456.

Kersten JT, H. Huang, dan C. Allen. 2001. Ralstonia solanacearum Needs Motility for Invasive Virulence on Tomato. J. Bacterioogyl 183(12): 3597.

Maharina KE, LQ. Aini, dan T. Wardiyati. 2014. Aplikasi Agens Hayati dan Bahan Nabati Sebagai Pengendalian Layu Bakteri (Ralstonia solanacearum) Pada Budidaya Tanaman Tomat. J. Produksi tanaman. 1(6).

Manjunath, D. Agsar, Jagannath, Rangaswamy, SC. Rao, S. Anand dan Yogisha. 2014. Characterization and In Vitro Efficacy Studies Of Wide Host Range Lytic Bacteriophage $\Phi$ dmec-1 Infecting Escherichia coli Isolated from Pyogenic Skin Infections. J. Trend in live science (2): 2319-4731.

Meng F, 2013. Ralstonia solanacearum Species Complex and Bacterial Wilt Disease. J. Bacteriol Parasitol 4:2.

Murugaiyan S, J.Y. Bae, J. Wu, S.D. Lee, H.Y. Um, H.K. Choi, E. Chung, J.-H. Lee dan S.-W. Lee. 2010. Characterization of Filamentous Bacteriophage PE226 Infecting Ralstonia solanacearum Strains. J. Applied Microbiology.

Nindita LO, dan AK. Wardani. 2013. Purifikasi Phage Cocktail Serta Spektrum Penghambatannya Terhadap Bakteri Penyebab Foodborne Disease. J. Teknologi Pertanian. Ind 14 (1): 47-56.

Resita SR, NF. Azizi, FES. Iriyanto, WC. Yuliasari, M. Kiptiyah, dan HS. Addy. 2014. Pengendalian Hayati Penyakit Hawar Bakteri Pada Tanaman Kedelai Dengan Menggunakan Bakteriofag. Prosiding seminar nasional. Bangkalan 18 Juni 2014.

Seleim MAA, a. Elyousr, A.Moneem, dan F. Saead. 2014. First Report of Bacterial Wilt Caused by Ralstonia solanacearum Biovar 2 Race 1 on Tomato in Egypt. J.Plant Pathol 30 (3):299-303.

Setiadi dan SF Nurulhuda. 2003. Kentang Varietas dan Pembudidayaan. Penebar Swadaya. Jakarta.

Snyder L, dan W. Champness. 2003. Lytic Bacteriophages: Genetic Analysis And Transduction. In: Molecular Genetics of Bacteria. Washington, DC: ASM Press, p: $231-274$

Susianto G, MM. Farid, NR. Dhany, dan HS. Addy. 2014. Host Range for Bacteriophages that Infect Bacterial Blight Pathogen on Soybean. Procedia Environmental Sciences. $760-766$.

Taj MK,. J. X. Ling, L. L. Bing, Z. Qi, I. Taj, T. M. Hassani, Z. Samreen dan W. Yunlin. 2014. Effect of Dilution, Temperature and $\mathrm{pH}$ on The Lysis Activity of T4 Phage Against E.coli BL21. J. Animal. Plant Sci 24(4):1252-1255.

Yamada T, T. Kawasaki, S. Nagata, A. Fujiwara A, S. Usami, M. Fujie. 2007. New bacteriophages that infect the phytopathogen Ralstonia solanacearum. J. Microbiology 153: 2630-2639. 
Fery Abdul Choliq, Mintarto Martosudiro, Istiqomah \& Muhammad Fanhash Nijami, 2020

Isolasi Dan Uji Kemampuan Bakteriofag Sebagai Agens Pengendali Penyakit Layu Bakteri

(Ralstonia solanacearum) Pada Tanaman Tomat. Journal Viabel Pertanian. (2020), 14(1)8-20

Yamada T. 2012. Bacteriophage of Ralstonia solanacearum: Their diversity and utilization as bioconhtrol agents in agriculture. In Tech.

Zhang L, J. Xu, J. Xu, H. Zhang, L. He, dan J. Feng. 2014. TssB is essential for virulence and required for Type VI secretion system in Ralstonia solanacearum. J. Microbial Pathogenesis 74:1-7. 